\title{
Risk Assessment and Control in Construction Projects
}

\author{
Zeeshan Sidiq Paul, Sandeep Singla, Manish Kaushal
}

\begin{abstract}
Construction tasks are initiated in changing and complex environments results in circumstances of excessive uncertainty and danger, that are compounded by means of worrying time Construction industry has modified significantly during the last numerous years. It is the industry driven on the whole via non-public investors; the existence of securitized immovable property has multiplied considerably. It is prone to the business and numerous technical dangers which represent higher exposures than risks which are traditional. Thus there is a need of Risk Assessment. Risk Assessment is a Process to discover those risks in

a assignment and manipulate it as a result with a right treatment. Assessment of Risk is described as a tool which identifies and measure

risk to personnel and belongings impacted by an assignment. The general technique of this Study depends largely on the questionnaire survey which become accrued from the local constructing contractors of different sizes with the aid of mail or by way of personnel meeting. A thorough review of literature is to begin with carried out to discover the hazard elements that have an effect on the overall performance of creation enterprise as a whole. The questionnaire survey is designed to probe the cross-sectional behavioral sample of production risks . The questionnaire organized for the pilot survey turned into formulated by means of seeing the applicable literature within the vicinity of creation risk management. Total seventy five businesses the questionnaires have been given, in which forty five had an powerful respond and two of them were rejected due to flawed answering. Thus the reaction rate is $60 \%$ which is taken into consideration a terrific response in this kind of survey. This studies seeks to become aware of and assess the dangers and to increase a risk control framework which the contractors/investing body can adopt while contracting creation work in Kashmir.
\end{abstract}

Index Terms: Risk Assessment, Construction

Revised Manuscript Received on February 05, 2020.

* Correspondence Author

Zeeshan Sidiq Paul, Masters of technology, RIMT University Punjab India .

Dr Sandeep Singla, Professor and Head of Department Civil engineering RIMT University Punjab India .

Manish Kaushal, Assistant Professor, Department of Civil Engioneering RIMT University, Punjab, India.

(C) The Authors. Published by Blue Eyes Intelligence Engineering and Sciences Publication (BEIESP). This is an open access article under the CC BY-NC-ND license (http://creativecommons.org/licenses/by-nc-nd/4.0/)

\section{INTRODUCTION}

Project management is the Critical Practice that Applies Knowledge of process, skills and techniques to venture activities so that you can meet or exceed stakeholder needs and expectations from a task. Risk management includes the approaches worried wit $\mathrm{h}$ identifying and analyzing, and responding to undertaking risk. Project risk Management aims to maximize the result of tremendous events and minimize the effect of unfavourable events.Risk management is a systematic way to assess and resolve future uncertainties. Project hazard control consists of the approaches worried with identifying, analyzing, and responding to assignment threat. It includes maximizing the results of wonderful vents and minimizing the outcomes of adverse activities Construction industries are vulnerable to the many different business dangers that often reflect more threats than those that would historically be insurable .there are for example, legislation and regulatory risks, market, compliance,professional,program risk inflation,contractual, aggressive and Economic,cultural risks, reputational, strategic, customer, legal, civic, Monetary risks

\section{RISK SOURCES IN PROJECTS CONSTRUCTION}

The Common place resources of chances in creation tasks are indexed below

- Misunderstanding of the terms and conditions of Contract

- Design modifications and errors

- Job with poor Coordination

- Inadequate estimates

- Undefined roles and responsibilities

- Unqualified Staff

- Human Threats

- Political problems

\section{OBJECTIVES OF THE STUDY}

1 To Explore the different risk factors in construction projects of kashmir

2 To analyze various factors of risk in construction projects of kashmir

3 To evaluate and endorse the techniques to manipulate a nd mitigate the risk Factors. 


\section{Risk Assessment and Control in Construction Projects}

\section{LITERATURE REVIEW}

Robert L. Tiong and Sudong Ye (2000) developed a qunatitaved class of current assessment approaches to build a brand new method - the net-present-value-at-chance (NPV) $t$ echnique through the combination of weighted average capital cost and dual hazards return strategies. The evaluation of hypothetical strength projects showed that the NPV at hazard methodology could provide a higher judgement for threat assessment and financing for private funded inrastructure tasks the major political dangers and pressures Based on their analysis of risk management of building operat e-transfer (BOT) in developing countries, with main

focus on infrastructure projects in China, Based upon survey, c ritical risks have been identified in order of

descending criticality: reliability and creditworthiness of Chin ese parties exchange in law, delay in approval, corruption, Also discussed are the measures to mitigate each o

$\mathrm{f}$ these risks.

\section{Makarand and Shake Aury}

For global development tasks called ICRAM-1, Makarand Hastak and Aury Shake (2000) developed a model for hazard assessment.The paper discussing some existing country hazar $\mathrm{d}$ assessment models, presents potential hazard signs at the ma cro, market and mission levels and explains the methodology of ICRAM

1 through an implemented example.ICRAM-1 analyzes obtain four key results: (1) Indicators of high risk (2)Effect of country surrounding on a particular undertaking (3)Effect of Business Surrounding on a particular task (4)Overall risk project;

Shaked and - Hastak (2000) in

their examine categorised all risks particular to entire creation situation into three levels, i.e Country, marketPlace and Assignment levels.the macroeconomics balance is related in part to the role of financial and economic policy an $d$ the susceptibility of a country to economic shocks

Building market hazards for an overseas company include tech nological advantage over nearby rivals, availability of producti on tools, complexity of regulatory processes, and the attitude o f neighborhood and overseas governments towards the constru ction industry, while task-level hazards are accurate to buildin $\mathrm{g}$ websites and include logistical constraints, faulty design, site protection,

Aleshin (2001) studied the hassle of hazard control l of global and joint project projects with overseas cooperation inRussia.The author has described classified and measured ris ks inherent in Russia's joint challenge initiatives and practical

chance management advice.

Based entirely on the survey, Shen et al (2001) set up a th reat significance index to highlight the relative significance of the risks associated with the joint ventures in the Chinese proc urement practice of development.. Real Cases were tested to assess the threat of joint ventures.
Shou Wang (2000) primarily addressed the criticality of

A questionnaire survey conducted by Saied A. Kartam ( 2001) found that contractors showed extra willingness to acce pt risks that could be contractual and jail-related as opposed to other types of risk.. In addition, their research showed that the implementation of structured chance analysis strategies within the Kuwaiti manufacturing industry is minimal

The financial hazard elements related to international prod uction ventures were identified from an included perspective $b$ y Prashant Chris Hendrickson and Kapila1 (2001).. We analyzed the best mitigation measures taken in dealing wit $\mathrm{h}$ these risks for their development projects by construction ex perts and suggest other means of hazard aversion..

Tarek Zayed (2002) developed a prototype evaluation mod el for BOT threat that is providing steady and reliable way to assess the risk of BOT mission the model proposed introduced the BOT chance index (F)that trusted the actual performance of eight major BOT risk areas. In the developement of this index, two exceptional modelling approaches were used, a complete newly evolved and adopted model of Dias and loannou .

Mervyn K Lewis and darrin (2002) examined the pronciples invloved in assessing measures to form a threat assessment process with the aid of the wastewater treat ment plant in Scotland as a standard assignment observation st udy..

Mohan.M.Kumaraswamy and Motiar rahman .M (2002) developed a primary version which, through a survey c onducted in Hong Kong and a case study in mainland China, c onceptualized improved project delivery with joint risk manag ement.

Alfredo del Can ) introduced a standardized project manage ment strategy that was specified by the owner and contractor who can assist the owner for construction projects.Next, the au thors describe a whole or standardized assignment control risk procedure to be carried out in the most relevant and complex development tasks with the assistance of organizations with th e highest level of risk management maturity. After that , Factors

affecting feasible simplifications of traditional method are est ablished, and for some cases simplifications are suggested.. A Delphi study was conducted as a very last test to validate the risk comtrol method outlined here and the results are given A Delphi study was conducted as a very last test to validate th e risk control method outlined here and the results are given.. The correct contracting method and the contract documents fo $r$ any construction activity depend on the nature of the underta king, but a reasonable contracting approach coupled with clea n And realistic contract contracts do not now allow such ventu re fulfillment by using them where people paint together with various interests and competing agendas in the face of uncertai nty and ambiguity...Contracting parties ' attitudes and cooperati ve relationships among the individuals involved in the underta king are crucial to successful delivery of challenges. 
These are discussed in the economic and relational contra cting (RC) concepts of low transaction value..It is observed th at $\mathrm{RC}$ could be a useful route closer to lowering transaction fe es, while also cultivating cooperative partnerships and strength ening cooperation that encourages joint threat management ( $\mathrm{J}$ $\mathrm{RM}$ ) during change.The latter's utility is reinforced by relevant findings from a most recent Hong Kong-based survey, follow ed by a case study in Mainland China.

Thomas al (2003) of IIT Madras conducted a threat belie $\mathrm{f}$ assessment to assess the criticality of hazard, capability to $\mathrm{m}$ anage hazard, preferential threat allocation / sharing, and elem ents influencing primary stakeholder risk recognition in BOT $\mathrm{t}$ asks.. They surveyed various senior individuals on the Indian BOT avenue programs, including government officials, develo pers, lenders and consultants.. In the indian road sector below BOT installation, eight hazard styles have been recognized as very important with revenue traffic risk chance beng the maximum

vital.The look at the variables and their relative have a dramati cally special effect on the risk attractiveness of stakeholders.

Wong and Hui and wong (2003)Stressed the Importance of hazard elements by information obtained in a $\mathrm{p}$ ostal survey of Hong Kong building contractors. Out of the 60 issues described , the existence of cash required uncertainty in the estimation of costs, immediate nee d for paintings, past experience with comparable interventions and duration of mediation are deemed to be the most relevant. The results suggested that in the increased adjustment of seaml ess rates, large-scale contractors should be more worried about the volatility of fee figures, even though medium- and low-sc ale contractors are more concerned about past experience.

Shen e al (2003) mounted an index of hazardous significa nce, mainly based on a study showing the relative importance of the hazards associated with joint ventures within the Chines e procurement practice of production. Real Case were investiagated to show the risk that the use of joint ventures $\mathrm{pr}$ esented to the community. The paper also examined reasonabl e threat management systems in the joint projects business ent erprise

Osama Jannadi and Salman Almishari created and co mputerized the RAM variant of a danger assessor to evaluate $t$ he risk associated with a particular value and reasoning eleme nt.

Daud Nasir e al (2003) developed a way to help determine the decrease and upper length of hobby values for scheduling chance assessment by system evaluation and analysis approac h evaluation or Monte Carlo simulation..

Possibility for multiple mother and father combinations for ea ch danger element was collected and integrated into the editio n through a specialist interview sample. Eventually, the measu rement of response is accomplished. The version modified to $\mathrm{c}$

heck the use of 17 case studies.
Sudong and Robert Tiong (2003) used the analysis of Monte Carlo to determine the mean net present value (NPV), v ariation and NPV-at-danger of various concession duration sys tems. To determine the viability of the plan, they evaluated the impact on the project characteristics on the concession duratio n model.They reached the conclusion that for both venture pro moter and host government, a very well designed concession 1 ength shape can create a ' win - win ' solution.

Hyun-Ho C.H.N. W. Seo and cho (2004) given an under building operation hazard assessment methodology. To evaluate and maintain the hazards involved in underground ma nufacturing, a formalized procedure and associated equipment

had been created. The cautioned process of threat assessment $c$ omprises of four measures to define, evaluate, determine and c ontrol the risks associated with development initiatives. The $\mathrm{k}$ ey device of the proposed risk assessment technique is the soft ware program for hazard assessment. The threat detection program is based primarily on a complex concept-based versi on of ambiguity. Certain methods built in this look at the surve y sheets to collect danger-related information and look at the $\mathrm{s}$ heets for threat identification and evaluation in depth.They dis cussed a detailed case study sooner or later on the advanced $m$ ethod of threat assessment finished for a Korean subway produ ction project.

Seung Han e. Al (2004) concentrated on monetary portfo lio vulnerability management for global activities to combine $t$ he hazard structure of both individual and company-level tasks , using a multi-criteria decision-making approach to optimize $\mathrm{t}$ he company's total profit. A case study was conducted to show the

approach based on actual tasks collected from a stylish corpor ate contractor. Through a workshop with industry practitioners , they finally provided learned training as well as suggestions $f$ or the usefulness of training to destiny activities.

Lyons and Martin (2004) done a survey on the use of c hance control techniques among senior management participat ing in the Queensland engineering production company.

Our results of the study are contrasted with four quantitative s urveys conducted around the field, which suggest that: the use of threat management is moderately high, with little difference between the forms, sizes and resistance of the organizations, a nd the man or woman respondents showing and disclosing risk tolerance; Risk regulation use in the implementation and prep aration of the life cycle of the enterprise is higher than in the $h$ ypothetical or termination phases; chance recognition and dan ger appraisal are the most widely employed risk management measures compared to chance reaction and risk documentation ; brainstorming is the highest, not uncommon, identity method used;Qualitative risk assessment approaches are used as often as possible; risk reduction is the most commonly used solution to risk response, by the use of contingency plans and agreeme nt conversion favored to insurance; and business associations are the most widely used agency for threat analysis, compared to in-house experts and professi onals. 


\section{Risk Assessment and Control in Construction Projects}

Ming Wang et. Al conducted multi-case studies using a comprehensive empirical approach to classify hazards in Taiw an's motorway projects, apprehend danger allocation through $t$ he use of contract clauses, and evaluate the hazard allocation e ffect on the contractor's strategic harm. The results show that th e proprietor allocates risks to five types of hazard distribution requirements by stipulating special compensation clauses. If a hazard is extra-controllable through the contractor, the contrac tor will be more inclined to delegate the danger to the contract or.

Danger management defines which types of danger could be faced by the contractor and affects the decision-making pro bability of the contractor.However, the study showed that if th e possibility of a certain risk occurrence scenario becomes unc ontrollable, then with the growing opportunity to take the chan ce, the contractor's propensity to cope with shifts from deliber ately moving the danger to passively retaining the threat.By co mparison, if a hazard is controllable and inevitably assigned to the provider, the builder simply takes the action to reduce the effect arising from the danger potential instead of maintaining the risk.

Shou Qing Al (2004) recognized twenty-eight critical ha zards correlated with global building projects in developing co untries and classified them into three levels of hierarchy ( mar ket, Country and project), 22 of which were assessed as critica 1 or very critical based primarily on a 7-degreering system. 11 top vital factors are: consent and authorize, reform of rule, str engthening of justice, creditworthiness of local partners, politi cal unrest, overrun of prices, abuse, inflation and cost

Councils, government policies, government influence on $\mathrm{J}$ $\mathrm{V}$ conflicts and termination.At the country level, the risks are more crucial than at the degree of the business and the latter ar e more relevant than during the degree of the project.It is sugg ested that the measures with better effectiveness should take $d$ elivery of a better priority after mitigating a selected hazard.Ta king into account the stronger criticalities of the higher level o f risk hierarchy, mitigation steps must also be prioritized by us ing the higher level of risk hierarchy, i.e.At a better organizati onal level, threats should first be mitigated with better precede

nt for their comparatively higher effective mitigations. A hazar $\mathrm{d}$ model, called the Risk Model of Alien Eyes, is being propos ed that shows the 3 degrees of risk hierarchy and the relationsh ip of impact between hazards.This edition would allow higher danger categorization and representation to affect the relations hip between hazards at particular organizational levels as well as to expose the mitigating sequence / priority of hazards.

Li bing Al (2005) performed a questionnaire study in the United Kingdom to discuss risk distribution options. Reaction awareness analysis indicates that some threats still need to be maintained or exchanged with the specific zone in the public a rea.These are mostly macro- and micro-level risks. Some threa ts, especially those within the macro stage chance group, must be assigned to the specific zone in PPP / PFI activities.

In the field of privatized infrastructure financing, Gill S. $\mathbf{M}$ (2006) established taxonomy for related definitions. The tax onomy is also an attempt to create database interoperability be tween the financial and technology industriesThe taxonomy di vides the funding requirements for a privatized economy into $\mathrm{s}$ ix main areas: methods, goods, programs, participants, materia ls and technical subjects (technical information and clear conc epts).

With Open Financial Exchange (OFX), the taxonomy is desig ned to be regular. It has evolved through the analysis of 10 cas e studies and cooperation with industry leaders in the develop ment of problems and interplay.The taxonomy was turned and confirmed by interactions with industry experts and by reviewi ng two unbiased case studies. To demonstrate the use of taxon omy, a prototypical semantic web interface for communicating task threats has grown..

Florence Yean Yng Ling and researched the dangers faced b y companies based in Singapore entirely in architectural, engin eering and manufacturing (AEC) operations in India and exam ined the hazard reaction approaches pursued across them.Data were gathered through in-intensity interviews with Singaporea $\mathrm{n}$ experts who were informed regarding AEC ventures in India .In contrast to the usual risks posed by a local project, the key hazards faced by AEC companies worldwide in India are: soci al and political risks; rising funding prices; fluctuating stock tr ading rates; and massive cultural differences between visitors and Indians.The methods of risk management consist of ok pr otection and careful planning and monitoring.Usually, using th em, it is recommended that foreign firms operating in India sh ould not now attempt to change the running of Indians.

Amarsinh B. (2016) has studied Construction sector Risk analysis.He stated "Risk is seen as a horrible term though it $\mathrm{m}$ ay have two dimensional in principle."The techniques discusse $\mathrm{d}$ in the RM literature are used by professionals in the manufac turing industries, but they are not informed..

Risks are handled within the organization every day, but not as organized as defined in the literature. As further verified by ot her studies, RM and RMP awareness is close to zero, despite $t$ he fact that the idea of chance management within the producti on area is becoming increasingly popular.Managing risk is a $p$ ractice which should be put into effect within a company in or der to achieve the company's goals. Therefore, spreading focus and creating hobby among people to use risk management str ategies within the industries are essential miles.

Aitwar Vishambar,, Patel Kartik, Ashwini Salunkhes (201 6) investigated motorway project case studies.The drift map of the special operation is important for better risk management preparation.Fair chance business strategy helps manufacturing companies to ever become aware of and mitigate the risks, and then, if properly managed, they can efficiently harvest cash sa vings and additional competitiveness, increase performance le vels with new ventures, and good selection.

N. V. Patil, Dr. P.G. Gaikwad (2015) perceives the dang er in street development In this paper during the lifecycle of th e road problem many and special varieties of risk are observed which can be considered key or minor chance based on their magnitude.The level of risk in this assessment has very dispro portionate score in the project stage of viability, design and tec hnology.It is important to use proactive approach rather than $\mathrm{r}$ eactive approach, which can only be applied by means of expe rience and the key threat manag ement compliance. 
Suchith Reddy looked at the construction industry as a c ase study.Risk management is strongly linked to the output se gment in this article.During this portion, most danger strategie $\mathrm{s}$ are undertaken and contractors are the most dynamic commu nity, with a first-rate impact on the hazard management cycle. Because of proven, probable or possible risks, owners and con tractors spend less time and effort to assess and prepare strateg ically. When we don't have a constructive strategy to reduce th e danger, the problems can arise in a project that decreases the delays and charges.

\section{RESEARCH METHODOLOGY}

The technique followed in this mission is given below:

1.Literature review of the strengths of analysis of risk and risk management

2. Preparation of Questionnaire.

3. Site visit to principal construction project sites.

4. Questionnaire survey and employees interviews with in-fees and executives and series of records from web page.

5. Analyzing the Questionnaire

6. Qualitative analysis of statistics obtained from website online and the root cause to be found

7.Suggest remedial steps and the latest figures for future comp arison to be recorded

8. Conclusions, hints and suggestions for Future study.

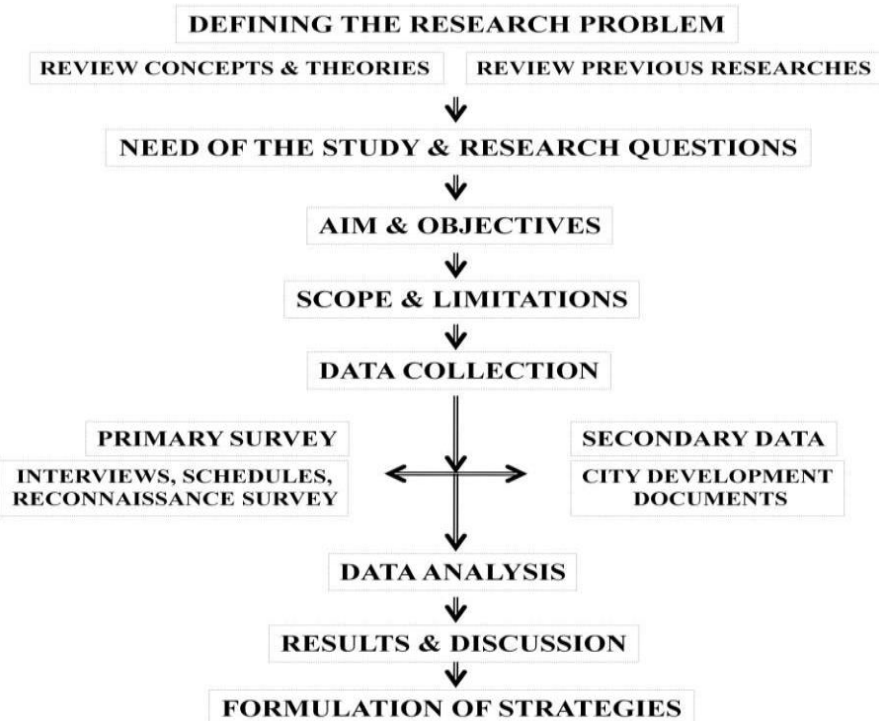

\section{MAJOR PROCESSES OF PROJECT RISK MANAGEMENT:}

Risk control involves 4 processes, namely

1. Risk Identification

Determine the risks that are likely affect the task and record $t$ he features of each.

2. Risk Quantification

Assessing threats and encounters of opportunity to determine $t$ he range of possible consequences of selection.
3. Risk Response Development

Defining enhancement steps for opportunities and responses to threats.

4. Risk Response Control

Responding to adjustments in chance over the course of the Project.

\section{METHOD OF SURVEYING}

The common approach of this is based largely on the sample questionnaire to be received by mail or workers conference fr om local construction contractors of various sizes.

Starting with a comprehensive literature review, the risk factor $\mathrm{s}$ influencing the success of the coSeveral workshops were als o performed with professional clinicians to create questionnair e feasibility checks.nstruction company as a whole were establ ished.

This observation has taken on the more fashionable and bro ad definition of risk presented by Shen (2001) on Chinese join $\mathrm{t}$ ventures in construction and much more factors from the oth er literary works.

In the questionnaire, a Likert scale of 1-5 was used. A Likert s cale is a form of psychometric response scale that is commonl $\mathrm{y}$ used in survey research and is the most frequently used meas ure..

Respondents indicate their level of agreement to a statement when answering a Likert questionnaire object.).

The respondents were required to specify the overall criticality / efficacy of each risk factor possibility and its effect on mana gement.

\section{DESIGN OF QUESTIONNAIRE}

The sample questionnaire is intended to test the cross-secti onal behavior pattern of the manufacturing industry regarding construction hazards. The questionnaire was structured for the pilot survey and modified into developed by seeing the related development threat literature. The interviewer became free to ask

detailed questions that focused on the problems that arose during the interview. The liberty to follow the questioner, ask for clarifications, and awareness of accurate projects, threat pr actices, and knowledge has rendered the interviews insightful.

\section{SURVEY DESIGN}

The participants were asked to assess the importance of eac $\mathrm{h}$ hazard or ' ' predicted failure '. ' There are many factors that could be regarded by the participants. An alternative approach proposed by previous researchers (Shen et. Al 1998) is to cons ider for each danger two attributes:The risk degree of hazard i ncidence, denoted by $\alpha$; and the damage graduation or failure point, whether chance happens, denoted by $\beta$. Also in this anal ysis is followed by the same method of assessment.

Hence, the sense of risk, referred to as RS, can be define $d$ as the function of the two attributes RS $=f(\alpha, \beta)$. The respon dents were asked to react to the two attributes for each hazard by using this technique. 


\section{Risk Assessment and Control in Construction Projects}

For consideration, the participants were asked to determi ne the degree of likelihood of hazard incidence by choosing on e of five categories, namely, Quite low, Low, Average, Large and Very large.

In order to consider $\beta$, the respondents had to judge the degree of effect if the risk involved occurs by selecting one of five gr ades, namely Very low, Low, Medium, High, and Very high.

\section{ANALYSIS OF RESULTS OF SURVEY}

In order to determine the relative importance of hazards, prio $\mathrm{r}$ literature proposes creating an index of danger severity by $\mathrm{m}$ easuring a value ranking for each hazard..

To measure the value rankingMultiply the probability of incid ence by impact degree.Thus, the value of significance can be c ollected through the model for each threat evaluated by each $r$ espondent.

$$
s_{j}^{\bar{i}}=\alpha_{j}^{i} \beta_{j}^{\bar{i}}
$$

Where in $\mathrm{Si}=$ significance rating assessed via respondent $\mathrm{j}$ for risk $i ; \alpha j=$ opportunity of occurrence of risk $i$, evaluated by means of respondent $\mathrm{j}$; and $\beta \mathrm{i}=$ impact degree of risk $\mathrm{i}$, evaluated through respondent $\mathrm{j}$. Through comparing scores from all answers, an average rating of value for each risk is far possible, and this average score is named the score of the risk index and is used to rate among all threats. The risk index estimation model can be published as

$$
R S^{i}=\frac{\sum_{j=1}^{i} S_{\tilde{l}}^{i}}{T}
$$

Where $\mathrm{RSi}=$ risk score index $\mathrm{i}$; $\mathrm{Si}$ = importance score evaluated by respondent $\mathrm{j}$ for risk $\mathrm{i}$ and $\mathrm{T}=$ Total respondants. This will be translated into numerical (Likert scale) measurements to measure $\mathrm{Si}$, the fi ve point scales for $\alpha$ and $\beta$.

\section{DATA ANALYSIS AND INTERPRETATION}

The participants were asked to assess the importance of eac h danger or " estimated failure '. ' There are many criteria that could be regarded by the participants.

An alternate approach introduced by previous researchers (She $\mathrm{n}$ et. Al 1998) is to assign characteristics for each hazard: the $\mathrm{d}$ egree of chance incidence, denoted by $\alpha$; and the degree of eff ect or magnitude of failure, if chance exists, denoted by $\beta$.

This research often approaches the same method of appraisal. Risk importance, referred to as RS, may therefore be defined a $\mathrm{s}$ the function of the two attributes RS $=\mathrm{f}(\alpha, \beta)$.

The respondents were asked to react to the attributes for each $\mathrm{c}$ hance by using this approach.For the purposes of reasoning, re spondents were asked to determine the likelihood of incidence by choosing one of 5 stages, namely Very Small, Average, Me dium and Very High..

In order to consider $\beta$, participants were required to determ ine the degree of effect if the possibility concerned exists by c hoosing one of 5 levels, including Really low, Low, Moderate, High, and Very large.So long as the contractor is concerned s hortage of skilled personnel has the highest threatscore and nu merous dangers that have high danger score include time const raint, subcontractor related issues, company failure, inaccurate inspection of contract records, and pressure from other compa nies.

Time limit for the owners has the highest hazard ranking and $\mathrm{n}$ umerous threats that have skilled workers ' high possibility sco re scarcity business lag, model drawing mistakes, improper pr oject management and budget management, loss because of rat e of inflationThe least dangerous score provided by means of both owners and contactors is environmental problem, interact ion with departments of government, local protectionism and $\mathrm{i}$ ndustrial disputes. 
Table 1 Overall Risk Ranking

\begin{tabular}{|c|c|c|c|}
\hline S.No & risk & Mean & $\begin{array}{l}\text { STANDARD } \\
\text { DEVIATION }\end{array}$ \\
\hline 1 & Scarcity of skilled workers & 5.57 & 4.62 \\
\hline 2 & Time limitation & 5.13 & 5.46 \\
\hline 3 & Problems related Sub-contractor & 4.59 & 6.23 \\
\hline 4 & Project delay & 4.33 & 6.73 \\
\hline 5 & Improper verification of settlement documents & 4.01 & 3.71 \\
\hline 6 & Competition from other Firms & 3.81 & 6.42 \\
\hline 7 & Improper undertaking of making plans and budgeting & 3.5 & 3.32 \\
\hline 8 & materials price Increase & 3.12 & 4.82 \\
\hline 9 & Loss because of changing inflation price & 3.15 & 3.68 \\
\hline 10 & Improper communication between different clients & 3.13 & 4.56 \\
\hline 11 & Loss because of change in interest rate & 3.34 & 6.39 \\
\hline 12 & Rise in costs of Labour & 3 & 6.92 \\
\hline 13 & Shortage of Material & 2.88 & 4.82 \\
\hline 14 & Internal control problems & 2.83 & 4.18 \\
\hline 15 & Breach of settlement by way of undertaking partner & 3.11 & 1.97 \\
\hline 16 & Improper Venture feasibility study & 2.85 & 2.33 \\
\hline 17 & Conditions of Unknown site & 2.96 & 2.41 \\
\hline 18 & Improper Venture organization structure & 2.76 & 4.12 \\
\hline 19 & Loss because of upward push in gasoline prices & 2.76 & 5.5 \\
\hline 20 & Design Adjustments & 2.73 & 3.75 \\
\hline 21 & distance from site to urban area & 2.6 & 6.23 \\
\hline 22 & Proper Team work & 2.59 & 3.72 \\
\hline 23 & Any hazardous effect on task due to climatic changes & 2.3 & 4.78 \\
\hline 24 & Errors in design drawings & 2.43 & 4.67 \\
\hline 25 & No experience in identical projects in past & 2.44 & 2.92 \\
\hline 26 & Less quality of procured site materials & 2.43 & 3.42 \\
\hline 27 & Materialswaste by means of workers & 2.33 & 4.22 \\
\hline 28 & Increase in cost because of changes in policies of govt & 2.58 & 3.39 \\
\hline 29 & Risk in Technical Aspect & 2.11 & 6.2 \\
\hline 30 & Lack of Clause of arbitration in agreement & 2.21 & 7.22 \\
\hline 31 & Disputes and poor relation with partner & 2.14 & 3.83 \\
\hline 32 & Higher degree of construction difficulity & 2.08 & 5.03 \\
\hline 33 & Rigid environmental regulations & 1.94 & 3.69 \\
\hline 34 & Lack of transportation facility & 1.85 & 2.93 \\
\hline 35 & Shortage of water Supply & 1.81 & 4.92 \\
\hline 36 & Failure in Equipment & 1.78 & 3.22 \\
\hline 37 & Unefficient choice of venture partner & 1.74 & 1.52 \\
\hline
\end{tabular}




\section{Risk Assessment and Control in Construction Projects}

\begin{tabular}{|c|c|c|c|}
\hline 38 & Loss due to late approvals from administration & 2.71 & 4.84 \\
\hline 39 & Structural vs Architectural Engineering dispute & 1.72 & 4.82 \\
\hline 40 & Surplus handling of materials & 2.72 & 5 \\
\hline 41 & Following government requirements and codes & 1.8 & 4.59 \\
\hline 42 & Bankruptcy of partner & 2.71 & 7.59 \\
\hline 43 & Site Accidents & 1.56 & 3.62 \\
\hline 45 & Increase in price of project accessories & 1.55 & 3.55 \\
\hline 46 & Loss due to exchange rate fluctuation & 1.45 & 3.34 \\
\hline 47 & Top managerial Changes & 1.42 & 2.55 \\
\hline 48 & Insufficent forecast about marketplace demand & 1.3 & 3.8 \\
\hline 49 & Lack of Legal enforcement Judgment & 1.22 & 2.72 \\
\hline 50 & Unjustified tendering & 1.22 & 4 \\
\hline 51 & Theft of substances at site & 1.22 & 4.01 \\
\hline 52 & Fall short of devised income from Project & 1.15 & 4.59 \\
\hline 53 & unfairness and Uncertainty in court justice & 1.7 & 2.52 \\
\hline 54 & protectionism from local people & 0.98 & 2.94 \\
\hline 55 & Changes in regulations and formalities of Bank & 0.94 & 3.77 \\
\hline 56 & Disputes of Industries & 0.88 & 3.57 \\
\hline 57 & Less credibility lenders and Stakeholders & 0.86 & 5 \\
\hline 58 & Short time in tendering process & 0.82 & 3.27 \\
\hline 59 & Obsoleteness of equipment in building & 0.8 & 2.36 \\
\hline 60 & Environment impact on project & 1 & 3.43 \\
\hline 61 & Healthy working surroundings for the workers & 0.81 & 3.8 \\
\hline 62 & Loss due to bribe and corruption & 0.78 & 6.59 \\
\hline 63 & Shortage in delivering electricity & 0.77 & 2.65 \\
\hline 64 & Loss because of political adjustments & 0.68 & 3.25 \\
\hline 65 & Poor relationship with administration & 0.56 & 2.1 \\
\hline
\end{tabular}

\section{FINANCIAL RISK}

While the rate of inflation remains much lower in India than

$\mathrm{n}$ industry has a heavy price. Increased fuel prices were also in many other developing nations, this is why the constructio behind increased inflation in India.

Table 2 Financial risks Ranking

\begin{tabular}{|c|c|c|}
\hline S No. & Risks & Mean \\
\hline 1 & Loss because of change in inflation rate & \\
\hline 2 & Loss because of change in interest rate & 3.01 \\
\hline 3 & Loss due to upward thrust in fuel prices & 2.99 \\
\hline 4 & Bankruptcy of partner undertaking & 1.63 \\
\hline 5 & Loss because of fluctuation of trade rate & 1.39 \\
\hline 6 & Changes in financial Procedure and Management & 1.01 \\
\hline 7 & Less reliability of stockholders and lenders & \\
\hline
\end{tabular}




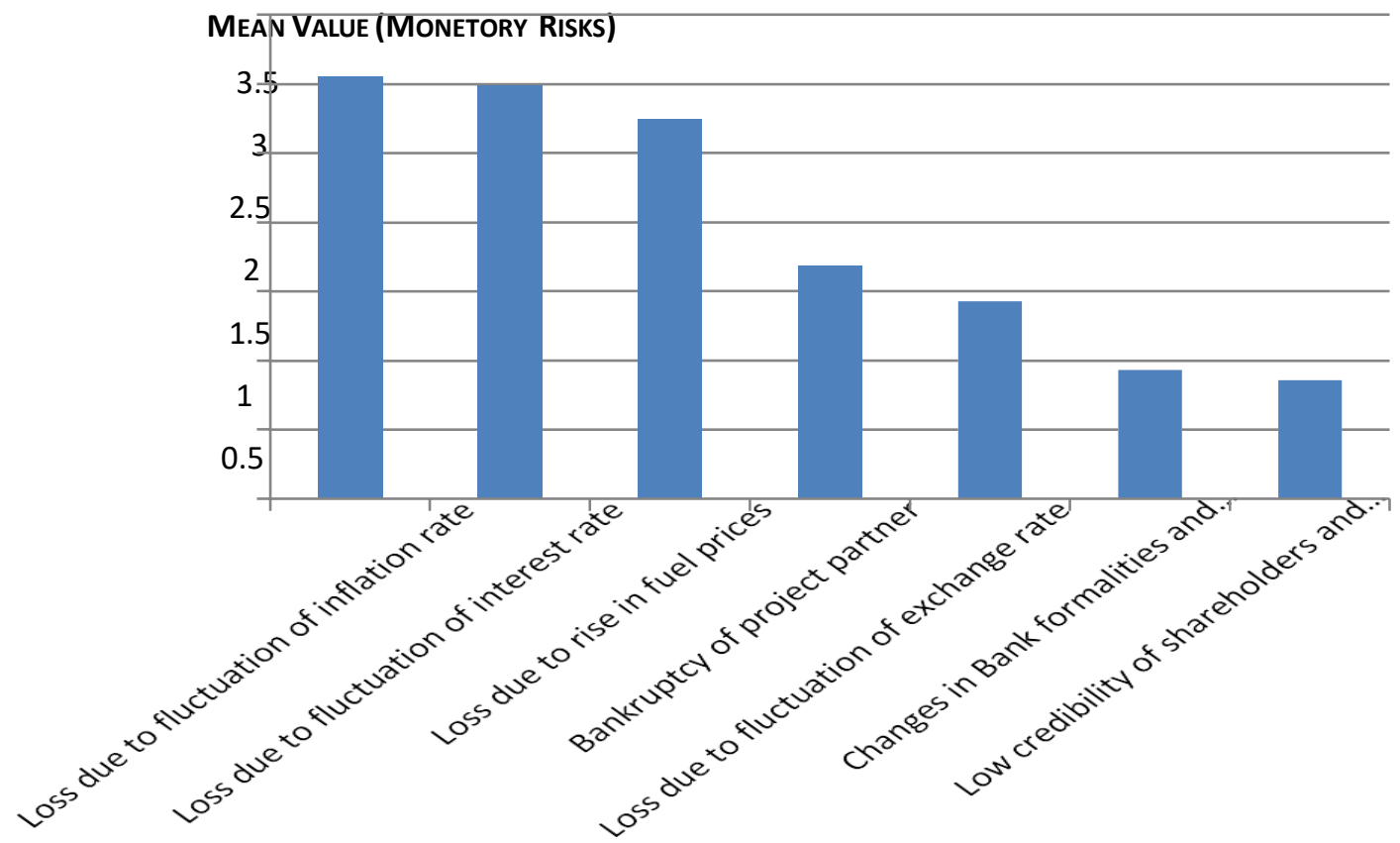

Figure 1 Bar Chart for Monetary Risks

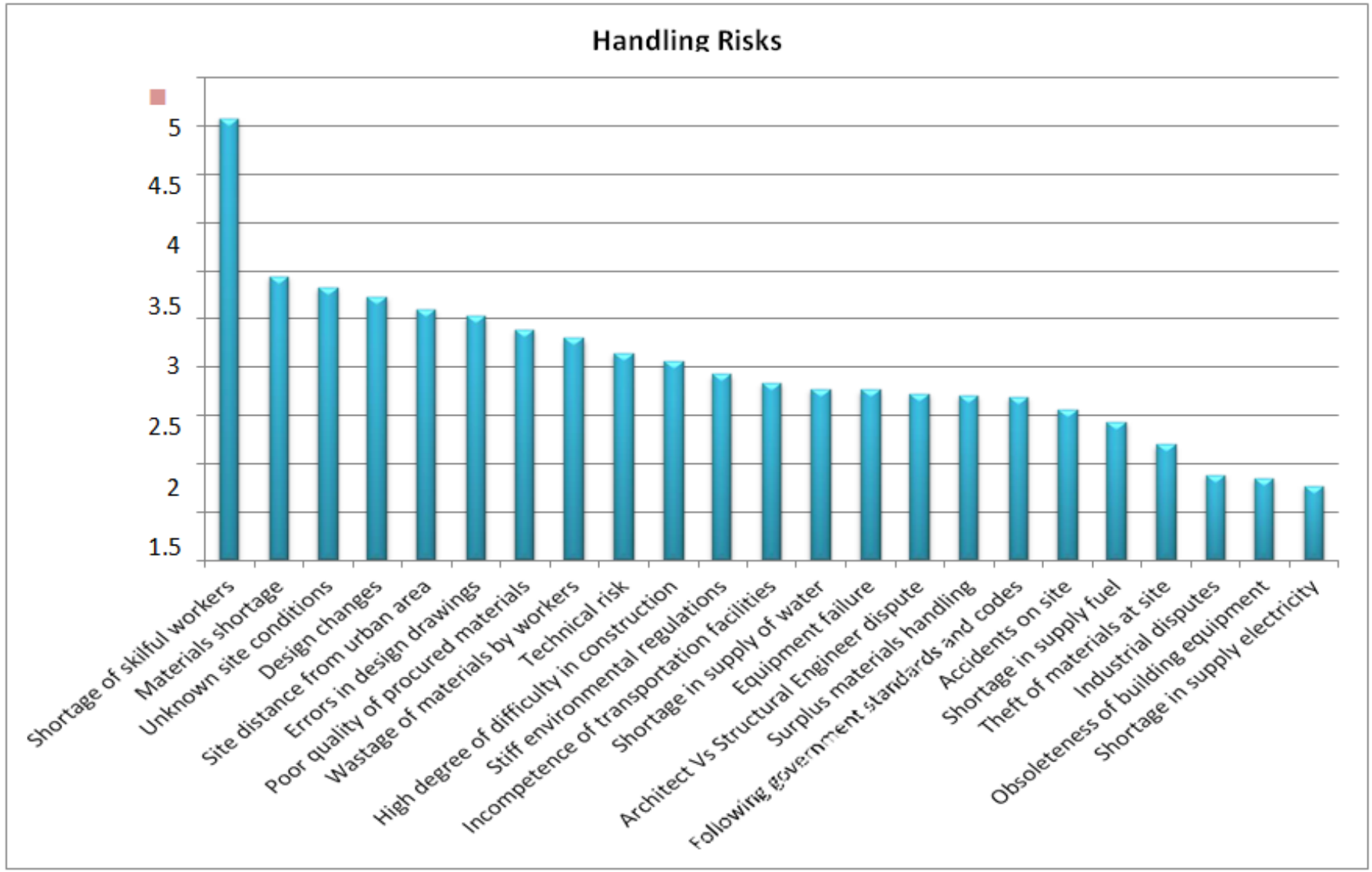

Figure 2 Bar Chart for Handling Risks

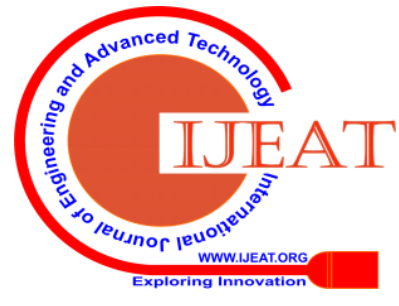




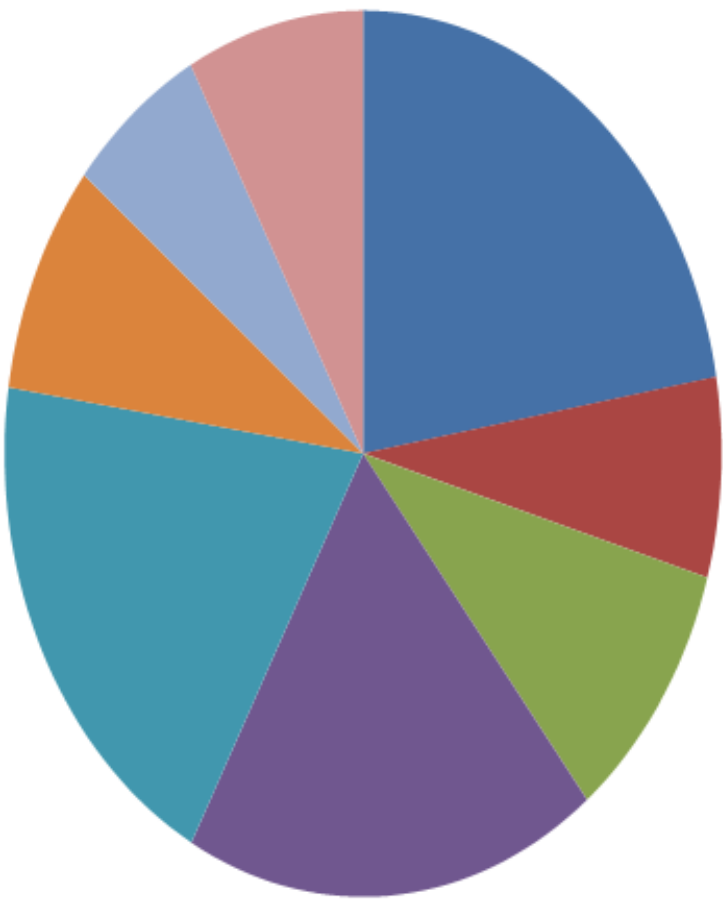

- Competition from different companies

- Fall quick of anticipated profits from project

Increase

of accent facilities price

Increase of labour costs

Increase of objective price

Inadequate forecast of Stock

- Protection from local people

Figure 3 Pie chart for market risk

\section{TECHNICAL RISK}

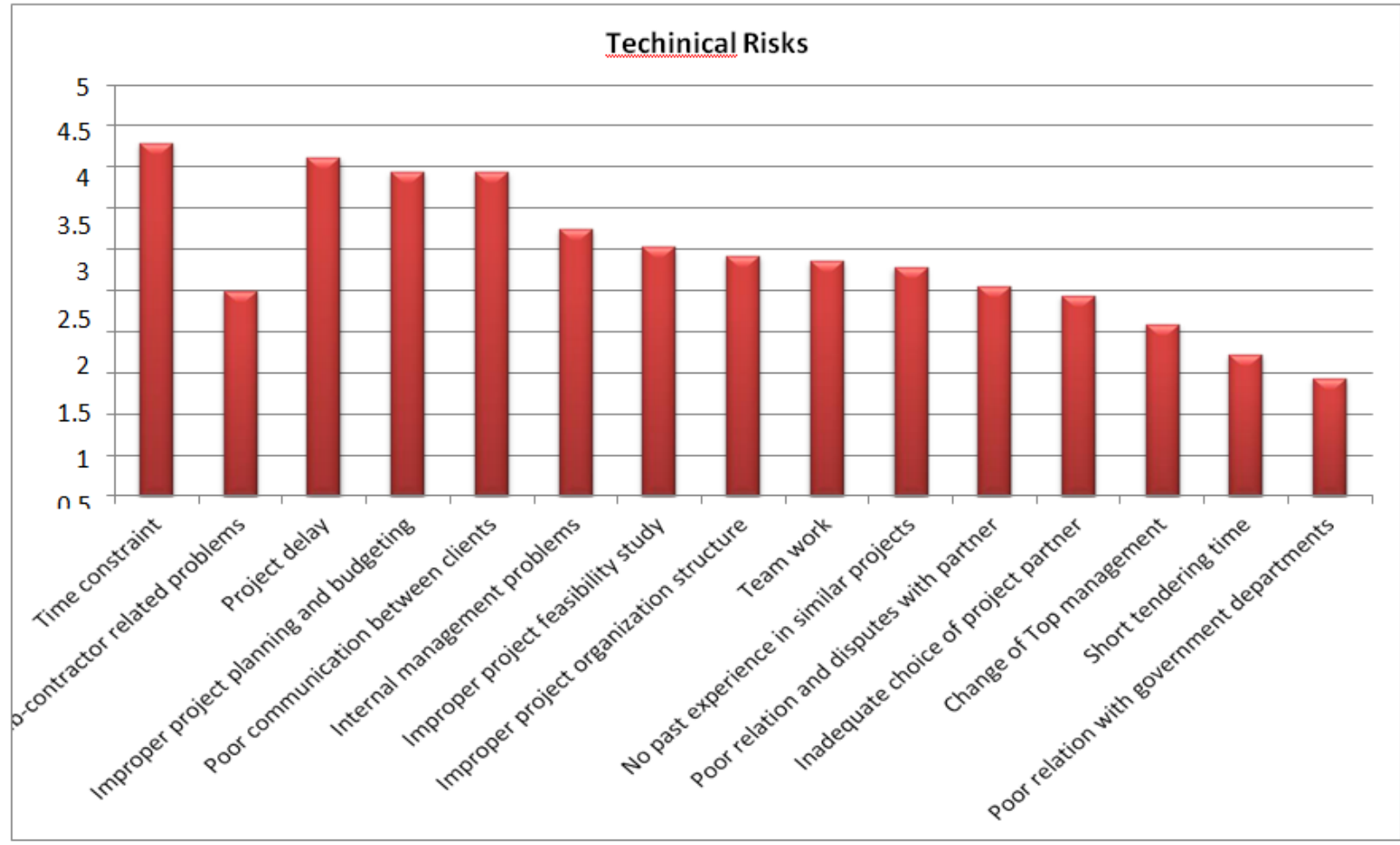

Figure 4 Bar chart for Technical risks

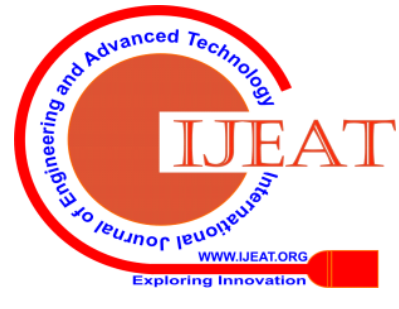




\section{POLITICAL RISK}

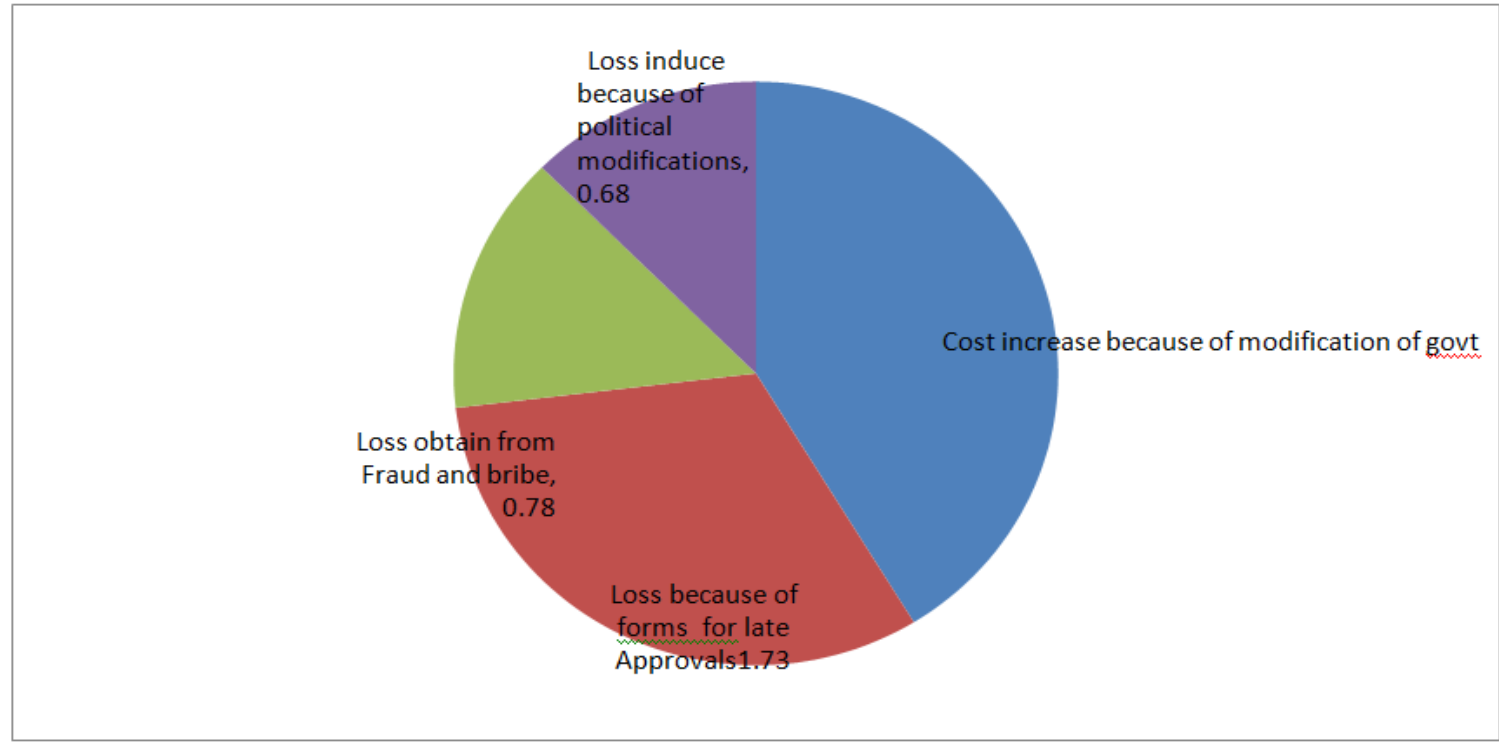

Figure 5 Pie chart for Political risk

\section{FINDINGS \& CONCLUSIONS}

Since some gap as far as India is concerned, risk manage ment remains a new word within the development field and thi s needs to be changed as quickly as possible.

A risk rating system is currently being developed by the Gover nment of India to enable builders create projects at a faster pac e by taking short decisions. Can company ranking may have it s own methodology for charging initiatives.

The device should help the government raise a risk mitigation process. It would elicit stronger reaction from constructors and customers to the actions of public sector collaborations. It sho uld increase the profitability of the bidding programs. The syst em will allow bankers to make short lending selections, which should cause the undertaking's economic closure at a faster pa ce. Third-party chance score will explicitly pose important poi nts that are typically not addressed at some stage when the assi gnment is completed.

1.Skillful people's lack is the biggest danger confronted by al most all organizations. That's because, most often because of th e high demand on the markets, skilled employees move betwe en classes.Workers migrate international locations in the Midd le East, where very powerful resources can be delivered comp ared to India, often create the wide gap.

2.Because the real estate sector is on the boom side, const ruction firms are in the process of making profit in the current wave itself as soon as possible;But this places enormous press ure on employees to finish the project within a very short perio $\mathrm{d}$ of time. In all the businesses analyzed, this time constraint $\mathrm{v}$ ulnerability prevails.

3. Contractor-related risks are also large, as most subcont ractors are unable to meet standards of the principal contractor and the customer due to their work size.From the above point $\mathrm{s}$, the danger of management was considered to be the essentia 1 risk of this study.
4.Project delay is the major risks, but this uncertainty is loope d directly or indirectly with various other factors and risks

5.The risk of competitiveness from other firms is a major problem for medium and small-sized firmsBecause of the Indi an government's policy of allowing 100 percent FDI in the con struction industry, which permitted foreign firms entering the market, local firms have created tough competition, both techn ically and economically.

6. Rate of inflation in India is quite high, and this rises pro portionately over time, leading to higher costs of commodities such as cement, steel that comes in, giving the land developers and construction firms financial risk.Banking institutions hav e also raised rates on their loan, which has had a major impact on the residential building market. The financial part of the da nger is therefore very high compared to any other risk.

7.The political risk for large companies is relatively quite low compared to other threats

8.Legal risks are very small, but the application of the court or der is not appropriate; this was the criticism is seen from this studyy.

9.Large firms agree that their proposal has few environmental effects, but argue it's a global phenomenon that can't be nullifi ed but can only be decreased..

10.Relative to other threats, the overall market, management a nd financial risks are high.

\section{REFERENCES}

1. A Reference to the Information Body of Project Management, (1996), P MI, Institute of Project Management.

2. Akintola S Akintoye and Malcolm J MacLeod, International Journal of P roject Management Vol, "Risk analysis and management in building." 1 5, Number 1, pp. 31-38, 1997 
3. Alfredo del Can, and M. Pilar de la Cruz, "Integrated Methodology for P rojectRisk Management," ASCE, December 2002, 473-485 4.

4. Artem Aleshin "Global Project Management Risk Management in Russi a," International Project Management Review Vol. 19, 2001, PP. 207-22 2

5. Bing, L., Tiong, R. L. K., Wong, W. F., and Chow, D, ' ' Global Constru ction Joint Projects Risk Management. " Journal of Building Technology and Management, 1999, ASCE, 125(4), 277-284

6. Darrin and Mervyn K Lewis, Global Review of Project Management 20 02, 107-118 "Evaluating the dangers of public-private collaborations for infrastructure projects"

7. Daud Nasir, Brenda McCabe and Loesie Hartono, Journal of Project Eng ineering and Management, ASCE, Vol. "Evaluating Hazard in Building - Plan System (ERIC - S) Construction Schedule Threat Method." 129 October 2003, Vol. 5, 518-527

8. Project taxonomy for funding privatized infrastructure: promoting conce ptual sharing of project risk knowledge" Construction Management and Economics, March 2006, 271-285.

9. Eric Verzuh, Wiley - 2nd Ed - 2005, 105-109 "The Quick Forward MB A in Project Management"

10. Garg. A.K.,(2005) "Construction Touch Risk Management," Acquisition of Building Materials, February 2005, 14-16.

11. Choi Hyo-Nam Cho Hyun-Ho and J. W. Seo "Underground construction project risk assessment approach" Building Technology and Manageme nt Review, ASCE, April 2004, 258-272

12. Joe Wong and Eddie C. M. Hui, "Construction project risks: further considerations for constructors pricing in Hong Kong", Construction Management and Economics, April 2006, 425-438

13. John Walewski and Edward Gibson. G, Jr., "Global Project Risk Assess ment," Center Business Studies Survey, Texas University, Austin, 2003, 11-15.

14. Li Bing and Robert L. K. Tiong, Journal of Construction Technology an d Management, ASCE, Vol. "Risk Management System for Global Cons truction Joint Ventures." 125, No.5, 377-384, September / October 1999

15. Li Bing, A. Akintoye, P.J. Edwards, C. Hardcastle, International Journal of Project Management 23, 2005, 25- "Risk management in UK PPP / P FI construction projects."

16. Likert R. "A Strategy for Attitude Measurement" Psychology Journals 1 40, 1932, 55.

17. Makarand Hastak and Aury Shaked "ICRAM-1: International Building Risk Assessment Model" Engineering Management Journal, Vol. 16, No . 1 of January 2000, ASCE, 59-69

18. Ming-Teh Wang and Hui-Yu Chou "Taiwan Highway Route Threat Allo cation and Risk Management" Journal of Engineering Security, ASCE, April 2003, 60-68

19. Rahman Motiar. M and Mohan. M. Kumaraswamy Construction Manag ement and Economics, 2002, 20, 45-54 "Joint risk management by trans actionally effective mutual contracting"

20. Mulholland. B and Christian. J "Risk Assessment in Construction Sched ules"Building Technology and Management Review, Vol. 125, Vol. 1, J anuary 1999, 8-15

21. Nabil A.Kartam and SaiedA.Kartam Project Management Magazine 19, 2001, 325-335 "Risk and its management within the Kuwaiti Constructio n Industry a contractor viewpoint"

22. Osama Ahmed Jannadi and Salman Almishari, Journal of Construction Engineering and Management, ASCE Vol, "Risk Assessment in Constru ction." 129, 492-500, No. 5, 2003.

23. Prashant Kapila and Chris Hendrickson, "Worldwide Building Projects Exchange Threat Protection" Journal of Engineering Management, Vol. 17, No. 4, October 2001.

24. The handbook of Ralph L. Kleim and Irwin S. Ludin Project Manageme nt Practitioner, Amacom Books, 93 - 96

25. Roozbeh kangari, Journal of Building Technology and Administration, Vol. "Risk management expectations and trends in U.S. growth." 121, N o. 4, 1995, 422-429.

26. Seung H. Han, James E. Diekmann, Young Lee and Jong H. Ock, Journa $\mathrm{l}$ of Construction Engineering and Management, ASCE, June 2004, 346356 "MulticriteriaFinancial Portfolio Risk Management for Foreign Proj ects"

27. Shen L Y "Hong Kong Project Risk Protection" Global Project Manage ment Vol Journal. 15, Number 2, 1997, 101-105

28. Building Technology and Management Review, ASCE, Vol. Shen L Y, George. W. C. Wu, and Catherine S. K.Ng "Risk Assessment for Buildin g Joint Ventures in China." 127, No. 1, January 2001, 76-81
29. Shou Qing Wang, Mohammad F. Dulami and Muhammad Y Aguria, Co nstruction Management and Economics, March 2004, 22, 237-252 "Risk management system for construction projects in developing countries"

30. Political vulnerability evaluation and control in China's BOT ventures " Building Technology and Control Review, Vol. 126, No. 3, May / June 2 $000,242-250$

31. Shou Qing Wang, Robert L. K. Tiong, Seng Kiong Ting, and David Ash ley, "Security risks: study of main clauses in the BOT mission of China, " Journal of Development Technology and Management, ASCE, June 19 99,190-197.

32. Sudong Ye and Robert L.K Tiong ' The effect of the architecture of the $c$ oncession duration on the successful completion of BOT projects, constr uction management and economics, 21, 471- 482

33. Sudong Ye and Robert L. K. Tiong "NPV-At-Risk Procedure of Assign mentInvestment Evaluation of Systems," Process Technology and Contr ol Review, June 2000, 227-233.

34. Tarek M. Zayed and the Engineering Management Review of Luh-Maan Chang, Vol. 18, Vol. 1, January 2002, 1, Seven-16

35. Terry Lyons, Martin Skitmore, International Journal of Project Manage ment 22, 2004, 5161 "Project risk management in the development secto $r$ of Queenslandengineering: a study"

36. Thomas E Uher and A Ray Toakley, International Journal of Project Ma nagement Vol, "Risk management in the mental portion of a problem."

37. Florence Yean Yng Ling and Linda Hoi, International Journal of Project Management 24, 2006, 261-270 "Risks posed by Singapore companies while setting up projects in India"

38. Thomas. A.V., Stayanarayana. N and Kalanindi "India Construction Ma nagement and Economy Threat Perception Analysis," June 21, 393-407

39. Florence Yean Yng Ling and Linda Hoi, International Journal of Project Management 24, 2006, 261-270 "Risks posed with the aid of Singapore firms while performing development activities in India"

40. Aitwar Vishambar1, Sontakke Kaustubh2, Patel Kartik3, Ashwini Salun kheRisk Management in Highway Project Construction: Case Study, Glo bal New Engineering and Technology Magazine Vol.2,Three MAR 201 6.

41. Mr. N. V. Patil, Roadmaking Risk Management, International Engineeri ng Journal, 2\&4,2015

42. Suchith ReddyRisk Construction Industry Management - A case study, multinational journal of advanced engineering know-how and managem ent research vol.4A, 10 OCT 2015

43. Krantikumar Mhetre, B.A.Konnur, Amarsinh B. Landage, Building Indu stry Risk Management, Global Technology Magazine Vol.5, 8 \& nine J AN 2016

\section{AUTHORS PROFILE}

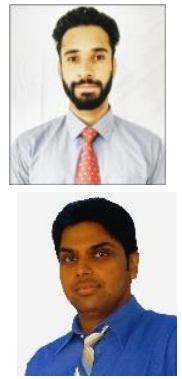

Zeeshan Sidiq Paul, Masters of technology Rimt University Bachelors of technology AMITY UNIVERSITY RAJASTHAN

Dr Sandeep Singla, PHD Scholar , Presently he is working as professor and Head of Department Civil engineering RIMT University Punjab India .Published more than 60 papers in national and international journals/conferences . Member of ISTE and a life member of IEI. drsandeepsinglaz@gmail.com

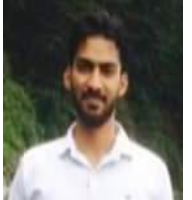

Manish Kaushal, received his B-Tech degree in civil engineering in 2011 from Pujab Technical University, Jalandhar, M-Tech from Punjab Technical University, Jalandhar in 2015. Presently, he is working as Assistant Professor in Department of Civil Engioneering RIMT University, Punjab, India.

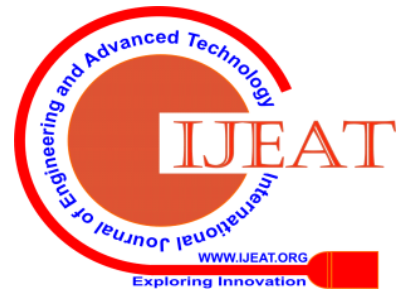

